\title{
Assessing the Variability of Tax Elasticities in Lithuania
}

Tigran Poghosyan 


\title{
IMF Working Paper
}

Fiscal Affairs Department

\section{Assessing the Variability of Tax Elasticities in Lithuania}

Prepared by Tigran Poghosyan ${ }^{1}$

Authorized for distribution by James Morsink and Abdelhak Senhadji

November 2011

\begin{abstract}
This Working Paper should not be reported as representing the views of the IMF. The views expressed in this Working Paper are those of the author(s) and do not necessarily represent those of the IMF or IMF policy. Working Papers describe research in progress by the author(s) and are published to elicit comments and to further debate.

This paper quantifies the variability of tax elasticities in Lithuania using two alternative methods: rolling regressions and pooled mean group estimator. The analysis is motivated by the systematic variation of tax revenues observed over the economic cycle in the recent past. Both methods confirm that tax elasticities moved with the cycle, which can be attributed to the procyclical tax compliance tendencies and structural composition effects across tax bases. Comparison of VAT revenue gaps across Baltic countries during the recent recovery suggests that tax revenues rebounded fastest in Estonia, followed by Lithuania and Latvia. Overall, the results of the study emphasize the importance of accounting for cyclical variation in tax elasticities when making short-term tax revenue projections.
\end{abstract}

JEL Classification Numbers: $\quad$ C32, C23, E32.

Keywords: tax elasticity, economic cycles, Lithuania.

Author's E-Mail Address: $\quad$ TPoghosyan@imf.org.

\footnotetext{
${ }^{1}$ I would like to thank Emanuele Baldacci, Thomas Baunsgaard, Dora Benedek, John Brondolo, Martin Grote, Jacques Miniane, James Morsink, Abdelhak Senhadji, and seminar participants at the European Department and the Ministry of Finance of Lithuania for helpful suggestions and comments, as well as Zhaogang Qiao and Gillian Adu for excellent research assistance. Audrone Mikneviciene from the Ministry of Finance of Lithuania has kindly provided the data. The usual disclaimer applies.
} 


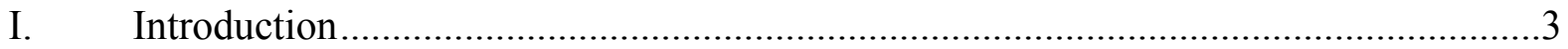

II. Related Literature on Estimating Tax Elasticities .........................................................

III. Brief Overview of the Lithuanian Tax System ........................................................

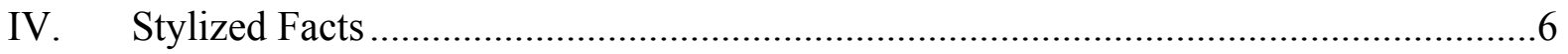

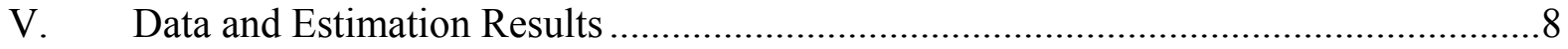

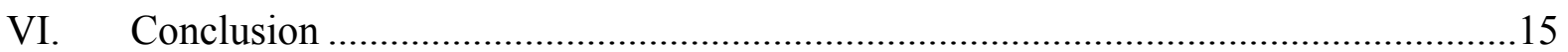

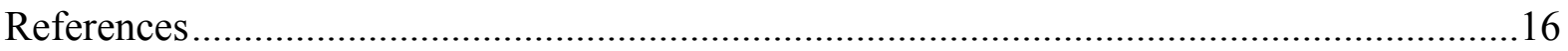

Tables

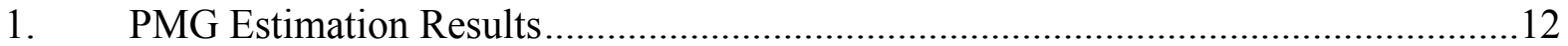

Figures

1. Trends in Tax Revenue Collections over the Last Decade ..........................................5

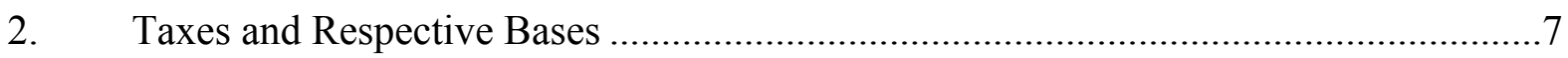

3. VAT C-Efficiency Across new EU Member Countries ..............................................

4. Time-Varying Elasticities from Rolling Regressions ..................................................10

5. Deviation of VAT Revenues from their Long-Run Equilibrium.................................14 


\section{INTRODUCTION}

Tax elasticities tend to vary systematically over economic cycles. Evidence suggests that tax revenues (including neutral and regressive taxes) tend to fall more sharply than their respective tax bases during recessions, and recover more strongly than bases during booms. Hence, using long-run tax elasticities for short-term revenue projections can lead to overestimation of revenues during contractions and to underestimation of revenues during booms.

The purpose of this paper is to quantify the variability of tax elasticities in Lithuania and assess where they stand at present. Tax revenues in Lithuania are prone to volatility due to: (i) the structure of the tax system, which relies highly on taxing flows (direct and indirect taxes) rather than stocks (wealth and immovable property), and (ii) macroeconomic flows, such as GDP, private consumption, and the wage bill, which are more volatile than the EU average. This paper analyzes the variability of elasticities for a range of taxes (value added tax - VAT, personal income tax - PIT, corporate income tax - CIT, and excise duties EX) over time, with a particular emphasis on the dynamics during the recent recession. We also analyze the cyclicality of standardized VAT revenue collections (defined as the ratio of VAT revenues to the country-specific statutory rates) in Lithuania relative to other new EU member countries, focusing on the deviations from the long-run equilibrium over the cycle.

We find strong evidence of cyclicality in the elasticity of VAT revenues in Lithuania. While the long-run VAT elasticity is close to one, revenue collections deviated from their long-run equilibrium up to 15 percent over the business cycle. Similar to other Baltic countries, deviation of VAT revenues from their long-run equilibrium in Lithuania was positive in the pre-recession boom period (2006-2008), but turned negative during the bust. The procyclical behavior of the revenue gap could be attributed to the procyclical tax compliance tendencies and structural composition effects across tax bases. At present, VAT revenues are rebounding to their long-run equilibrium, but remain about 5 percent short of it as of end-2010.

The PIT, CIT, and EX elasticities also vary with time, but their dynamics is not fully synchronized. As expected, the PIT and CIT elasticities exceed unity in most part of the sample given their progressivity. The CIT elasticity exhibits the widest range of variation (mainly due to uneven schedule of CIT payments within the year), followed by the EX elasticity. All elasticities have exhibited some increase during the recent recovery, but with different intensity.

The rest of the paper is structured as follows. Section II provides a selective literature overview. Section III presents a brief overview of the Lithuanian tax system. Section IV discusses stylized facts. Sections V present estimation results for rolling regression and panel data methods, respectively. The last section concludes. 


\section{RELATED LiterATURE ON ESTIMATING TAX ELASTICITIES}

Most methodological approaches focus on estimating long-run tax elasticities, which are supposed to be constant assuming no changes in the tax system. These approaches are motivated by the observed cyclical adjustment of government revenues and fiscal balance, for which tax elasticities serve as key input. A widely cited reference is Girouard and Andre (1995), which follows the "disaggregated approach" for the cyclical adjustment of government revenues. The authors calibrate elasticities of individual tax categories with respect to their respective bases for 20 OECD countries using tax codes and legislation. These elasticities are then multiplied by the elasticities of tax bases with respect to the output gap to obtain overall tax elasticities that enter the calculations of cyclically adjusted balances. In line with the intuition, the study finds that personal and corporate income taxes are progressive (elasticity is above one), social security contributions are regressive (elasticity is below one), while indirect taxes are neutral (elasticity close to one). ${ }^{2}$ In contrast to Girouard and Andre, Fedelino et al. (2009) and Congressional Budget Office (2009) follow an "aggregated approach", in which elasticities with respect to the output gap are calculated for aggregate government revenues.

\section{Despite the long-run constancy assumption, several studies have found that tax} elasticities may temporarily deviate from their long-run estimates. One important set of factors contributing to the time variation of elasticities are beyond the cycle effects. While business cycle is the most prominent source of government revenue fluctuations, these revenues can also be affected by shocks related to the boom-and-bust cycles of assets, property prices, and commodity prices, which are not always correlated with the business cycle. For example, Aydin (2010) argues that beyond the cycle effects played a prominent role in explaining highly volatile tax elasticities in South Africa. Another set of factors is related to changes in the output composition (Bornhorst et al., 2011). For example, an economic expansion driven by private consumption will have a much larger impact on tax collection than an export-driven expansion. Cyclical adjustment does not account for the composition effect, as it only considers the output gap, which could be the same under both scenarios. Finally, tax elasticities can be affected by changes in tax compliance, since firms and households are more likely to evade taxes when they are credit constrained or financially depressed. For example, Brondolo (2009) suggests that during the financial crisis tax compliance declines as taxpayers began to delay tax payments. According to basic models of tax compliance, taxpayers facing economic stress or bankruptcy may perceive the downside risk of tax evasion (penalties) to be smaller compared to the potential upside gains (avoiding bankruptcy). In addition, shift in economic activity from formal to the informal sector may increase during the downturns, contributing to the cyclicality. Similarly, Sancak et al. (2010) show that the efficiency of VAT collections tends to be lower in "bad" times (when the output gap is negative and informal economy is expanding), and vice versa. In a cross-

\footnotetext{
${ }^{2}$ In case of the VAT, the elasticity is set to unity without conducting any estimations.
} 
sectional dimension, it was shown that emerging countries with institutions that are less conducive to tax compliance practices tend to have higher efficiency in VAT collections (Agha and Haughton, 1996, De Melo, 2009, and Aizenman and Jinjarak, 2008).

\section{BRIEF OVERVIEW OF THE LITHUANIAN TAX SYSTEM}

The overall tax burden in Lithuania at about 30 percent of GDP is lower than the EU average. The proportion of tax revenues received by the central government is slightly below 50 percent, local governments receive about 12 percent of total tax revenues, and the rest is being received by the social security and extra budgetary funds. Between 2001-2010, indirect taxes comprised 60 percent of total tax revenues and 35 percent of total government revenues (Figure 1). VAT and EX are the main indirect taxes, comprising 38 and 16 percent of total tax revenues, respectively, while PIT and CIT are the main direct taxes, comprising 32 and 10 percent of total tax revenues, respectively. Other taxes constitute the remaining 4 percent of the total. ${ }^{3}$

\section{Figure 1. Trends in Tax Revenue Collections over the Last Decade}
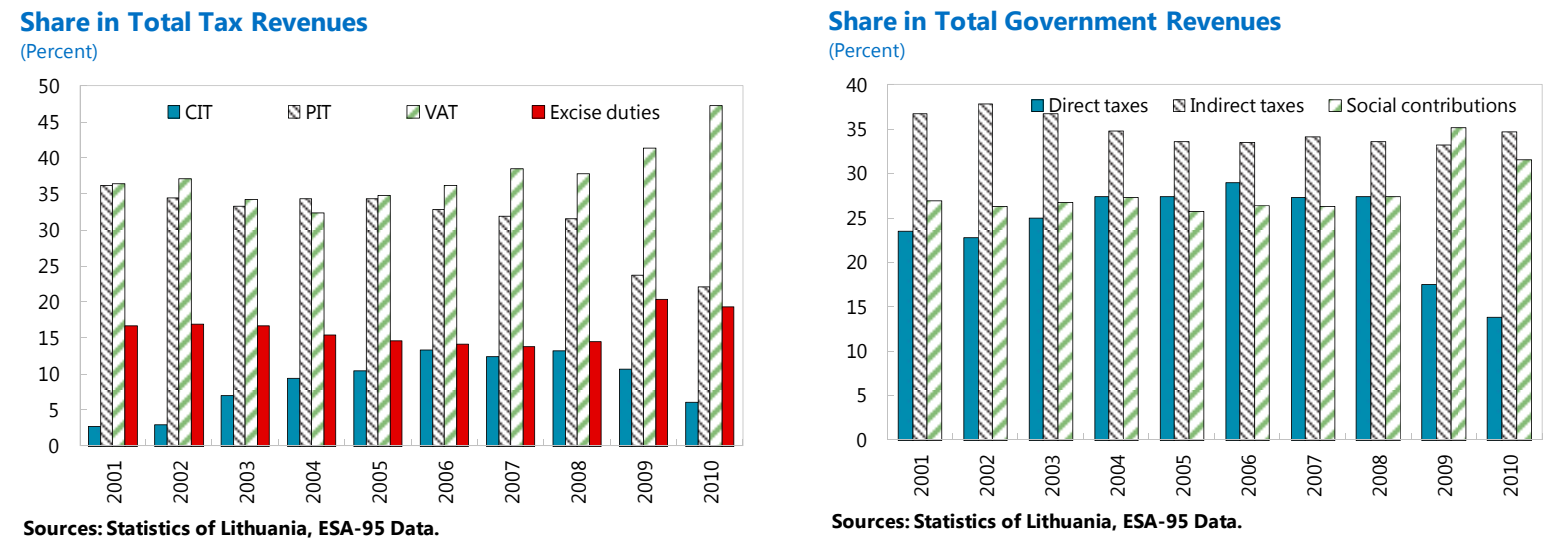

The tax structure relies on taxing income and consumption (flows), while taxes on wealth and capital (stocks) are among the lowest in the EU making tax revenues vulnerable to economic fluctuations. The main taxes in Lithuania are PIT, CIT, VAT, and EX. The main characteristics of these taxes broadly correspond to the ones elsewhere in the $\mathrm{EU}^{4}$, although it is important to note that CIT and PIT rate changes are easier to implement unilaterally in comparison to VAT and excise duties which face tougher harmonization constraints at the EU level. The tax structure relies on taxing income and consumption

\footnotetext{
${ }^{3}$ IMF (2010) reviews the structure of the Lithuanian tax system.

${ }^{4}$ Comparison tables are provided in the most recent periodical on taxation trends in the European Union (see European Commission, 2011).
} 
(flows), while taxes on wealth and capital (stocks) are among the lowest in the EU making tax revenues vulnerable to economic fluctuations.

Social security contributions in Lithuania are comparable to the regional average. Social contributions are counted separately from tax revenues and their importance has increased from 2009, when compulsory health insurance contributions have become part of social contributions. The contribution rates were on an upward trend in Lithuania during the last decade, growing from 9.2 percent in 1999 to 11.6 percent in 2009. The 2009 contribution rate of 11.6 percent of GDP corresponds to the average collection in the new EU member countries for the 1999-2009 period.

Revenues from property and land taxes are relatively modest. Lithuania collected only 0.37 percent of GDP in property and land taxes in 2010. At present, only commercial property is taxed in Lithuania, with the annual tax being set by the municipalities in the 0.3-1 percent range. Unimproved land is taxed at 1.5 percent, but numerous exemptions and base reductions apply narrowing the taxable base substantially. There is no net wealth tax.

\section{STYLIZEd FACTS}

Prima facie evidence hints at time-varying tax elasticities in Lithuania. On the whole, tax revenues contracted more sharply than their respective bases during the recession (Figure 2) and tax revenues are rebounding at a faster pace than their bases since the beginning of the recovery in 2010. For example, between 2008-2009 VAT collections declined by 25 percent, compared to a 14 percent drop in nominal private consumption during the same period. In contrast, during 2009-2010 VAT collections grew by 12 percent, compared to a 3 percent decline in private consumption. The VAT revenue growth outpaced that of private consumption also during the pre-recession boom period. This divergence of tax growth rates and their bases over the cycle is also driven by changes in tax policies, which we account for in our econometric analysis. ${ }^{5}$ Nevertheless, the comparison of growth rates provides some indication of a time-varying nature of tax elasticities that we would like to quantify.

\footnotetext{
${ }^{5}$ European Commission (2011) contains detailed description of major tax system changes in Lithuania before and during the crisis (see pages 215-217). Specifically, in 2009 VAT statutory rate was raised from 18 to 21 percent, PIT statutory rate was reduced from 24 to 21 percent, CIT statutory rate was temporarily raised from 15 to 20 percent and then reversed back to 15 percent, and EX rates on fuel, alcohol, and tobacco have changed to comply with the EU regulation.
} 
Figure 2. Taxes and Respective Bases
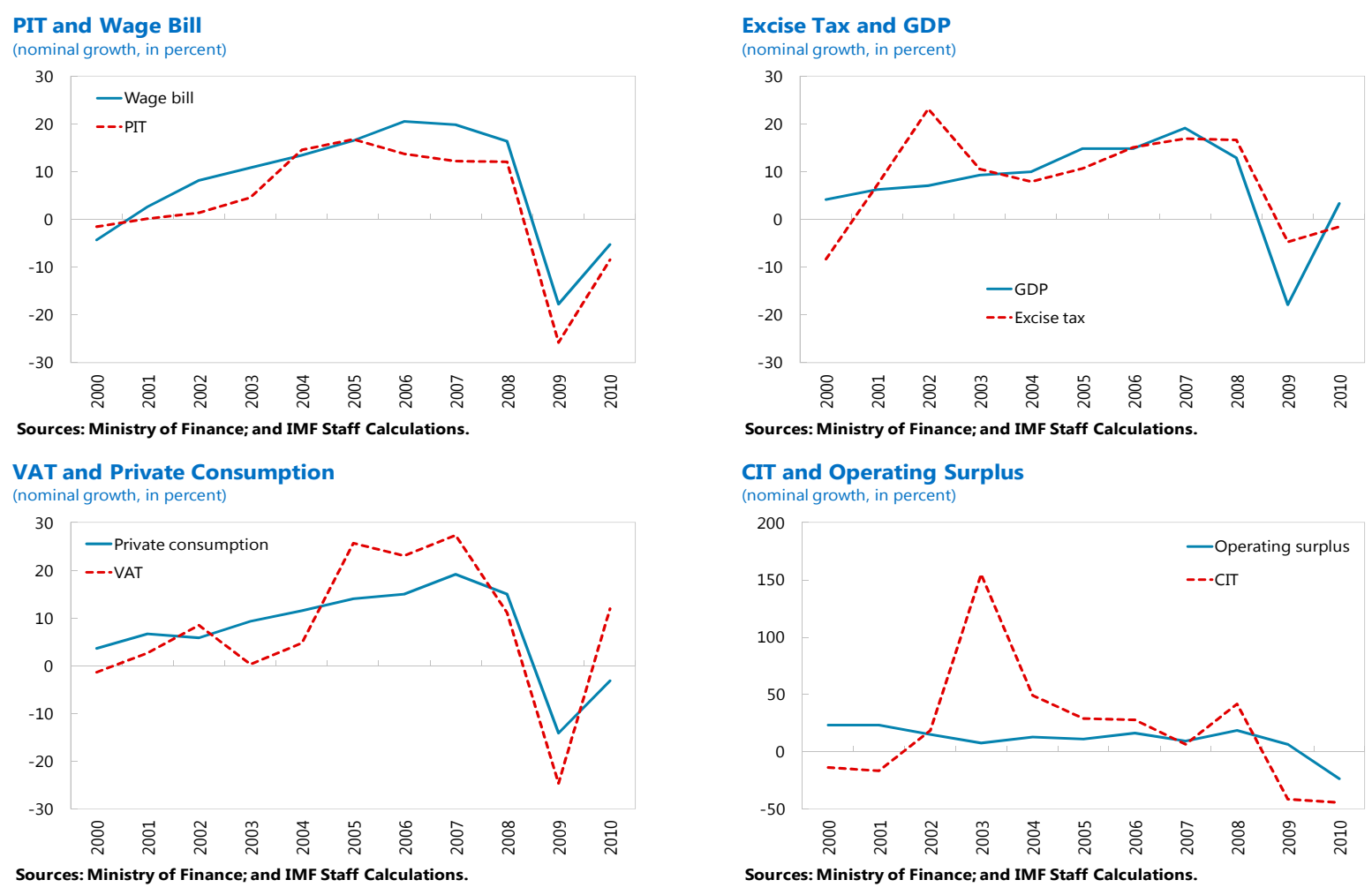

For a panel of new EU member countries, analysis of the VAT C-efficiency scores further highlights fluctuations over the cycle as well as across countries. The VAT Cefficiency scores are obtained by dividing the VAT revenue to personal consumption ratio over the VAT statutory rates obtained from the European Commission. ${ }^{6}$ The efficiency scores vary widely across the countries in our sample (Figure 3), with Poland falling in the lower end of the distribution (median score is 55 percent), while Estonia in the upper end (median score is 85 percent, which is very high by international standards). More relevant for our analysis, the efficiency scores also moved widely over time (Figure 3): starting from a median of 57 percent in 1999 they reached a peak of 72 percent in 2007 (pre-recession), and then returned back to 62 percent in 2010 (recovery). The dispersion of scores across countries has also varied across time, recording the lowest range during the pre-recession peak in 2007.

\footnotetext{
${ }^{6}$ Higher score reflects more efficiency, and vice versa. Median scores are reported instead of averages to alleviate the impact of outliers and extreme observations.
} 


\section{Figure 3. VAT C-Efficiency Across new EU Member Countries}
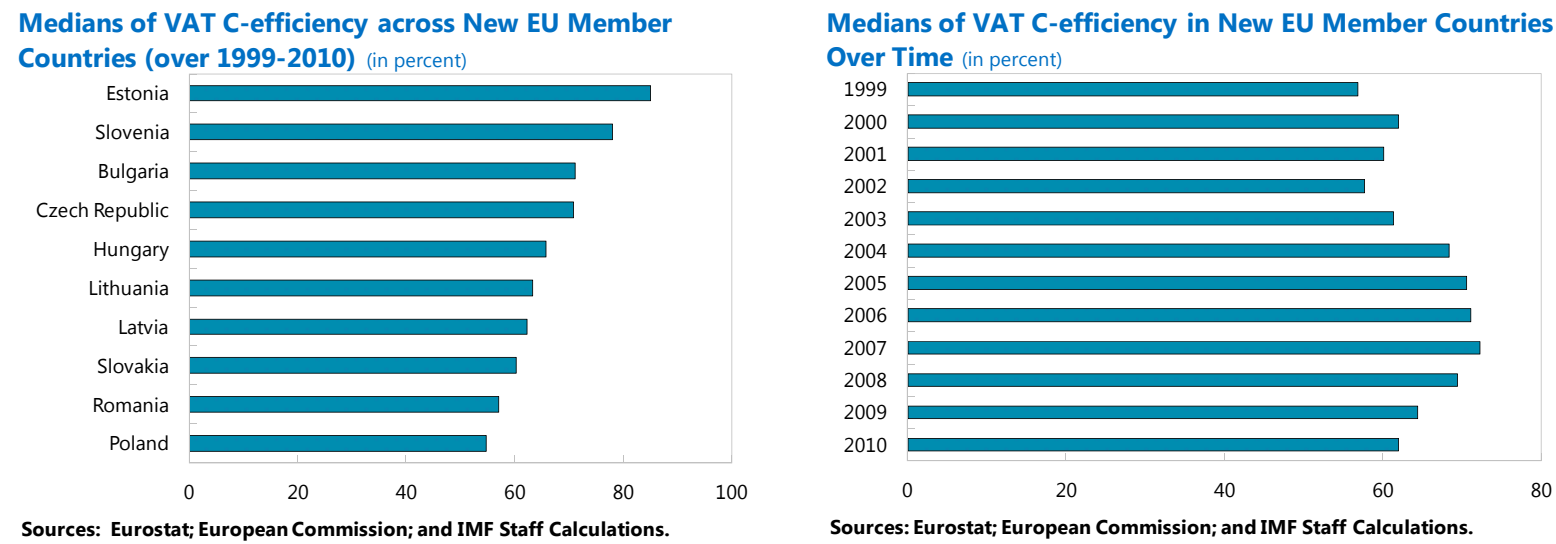

\section{DAta AND ESTIMATION RESUlts}

We use quarterly data on taxes and their bases for the 1999-2010 period. Data on VAT, PIT, CIT, and EX for Lithuania, as well as changes in tax systems (based on which control dummies are generated), are obtained from the Ministry of Finance. Information on tax bases, including GDP, personal consumption, wage bill, operating surplus, is taken from the Statistics of Lithuania. We also use a panel data on VAT revenues and personal consumption for 10 new EU member countries from the Eurostat. The new EU member countries used in the analysis are: Bulgaria, Czech Republic, Estonia, Latvia, Lithuania, Hungary, Poland, Romania, Slovenia, and Slovakia.

We use two methodologies to assess the variability of tax elasticities. First, we apply rolling regression methods to individual taxes in Lihuania. The advantage of this method is that it allows comparing tax elasticities estimated for different subsamples. The drawback is the limited precision of obtained estimates due to the absence of sufficiently long time series. Second, we apply panel data methods to VAT collections in new EU member countries. This methodology overcomes the above mentioned limitation by expanding the number of observations across countries. It also allows comparing revenue collection performance across countries and accounts for substantial part of tax revenues given that new EU member countries largely rely on VAT. However, it cannot be applied to PIT, CIT, and EX, since it is more difficult to measure efficiency for these taxes relative to VAT given considerable differences in tax systems across countries (income distributions, multiple tax brackets, etc.). Unfortunately, the analysis of tax elasticities for social contributions was not possible to conduct given the absence of the pre-2004 quarterly data. 


\section{Rolling regressions}

Tax elasticities can be derived from the relationship between cyclical fluctuations in tax revenues and their bases. The following relationship has been commonly used as benchmark in the literature (e.g., Bornhorst et al., 2011):

$$
T=T^{*}\left(\frac{B}{B^{*}}\right)^{\varepsilon}
$$

where $T$ is the tax revenue, $T^{*}$ is the structural tax revenue, $B$ is the tax base, $B^{*}$ is the potential tax base, and $\varepsilon$ is the tax elasticity $(\varepsilon>0)$. Depending on the magnitude of $\varepsilon$, the tax system can be progressive $(\varepsilon>1)$, regressive $(\varepsilon<1)$, or neutral $(\varepsilon=1)$. The empirical assessment of tax elasticities is based on equation (1):

$$
\ln \left(\frac{T_{t}}{T_{t}^{*}}\right)=\beta_{0}+\beta_{1} * \ln \left(\frac{B_{t}}{B_{t}^{*}}\right)+\beta_{2} * \operatorname{CONTROLS} S_{t}+v_{t}
$$

where $\beta_{1}$ is the estimate of the tax elasticity $(\varepsilon), T^{*}$ and $B^{*}$ are estimated using the HodrickPrescott (HP) filter for each tax (VAT, CIT, PIT, and SC), and CONTROLS is a vector of dummy variables to control for changes in the corresponding tax systems (including changes in statutory rates, exemptions, etc.).

One drawback of equation (2) is its reliance on the potential tax and tax base estimates obtained through the HP filter. The limitations of HP filter as a tool for disentangling the trend and cyclical fluctuations in emerging markets featuring short time series and frequent structural changes have been documented widely (e.g., De Masi, 1997). Therefore, one could estimate equation (2) using differences of $\mathrm{T}$ and $\mathrm{B}$, instead of their deviations from potential, to avoid relying on HP filter results: ${ }^{7}$

$$
\Delta \ln \left(T_{t}\right)=\beta_{0}+\beta_{1} * \Delta \ln \left(B_{t}\right)+\beta_{2} * \operatorname{CONTROLS}_{t}+\varepsilon_{t}
$$

\section{Rolling window regression methods are used to capture the time variation in tax} elasticities from equation (3). A fixed moving window of 28 quarters (7 years) is used in each estimation. ${ }^{8}$ Given the seasonal volatility of the series, year-on-year percentage changes are used for both $T_{t}$ and $B_{t}$. The obtained elasticity estimates together with their upper and lower bounds (computed as \pm 2 s.d. around coefficient estimates) are plotted to assess both the dynamics and significance of elasticities.

\footnotetext{
${ }^{7}$ Equation (3) can be derived from equation (2) by assuming constant growth rates in $B_{t}{ }^{*}$ and $T_{t}{ }^{*}$. For the estimation purposes, we take $y-0-y$ differences to account for the seasonality effects.

${ }^{8}$ Robustness checks using moving windows of different sizes produce qualitatively similar results.
} 


\section{Figure 4. Time-Varying Elasticities from Rolling Regressions}

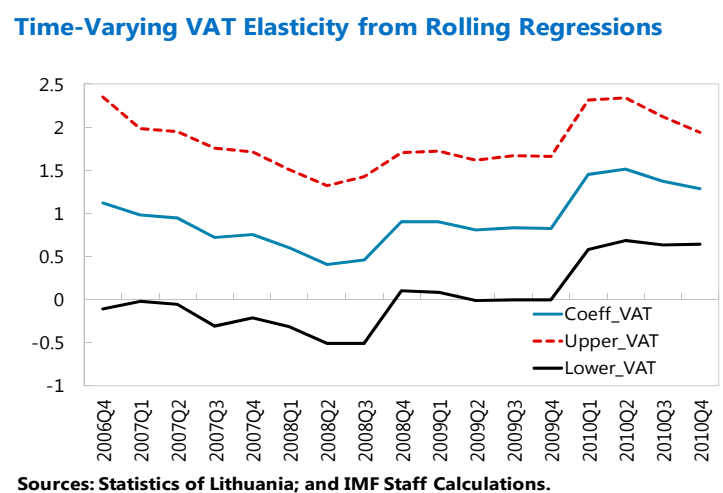

Time-Varying PIT Elasticity from Rolling Regressions

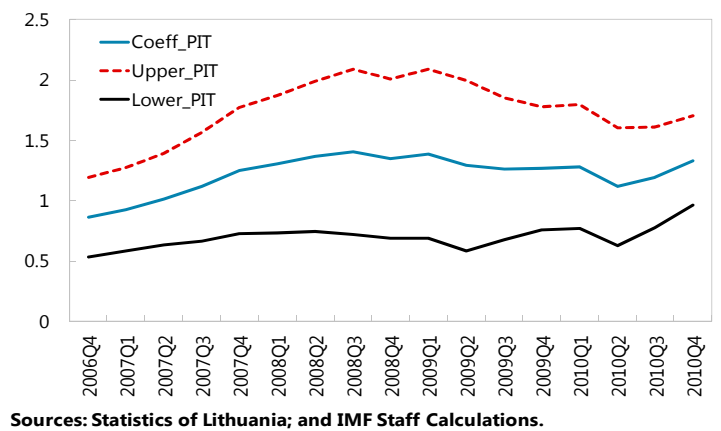

Time-Varying CIT Elasticity from Rolling Regressions

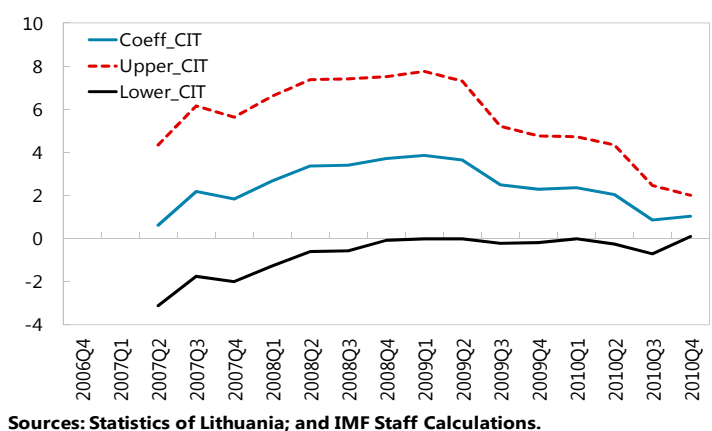

Time-Varying EX Elasticity from Rolling Regressions

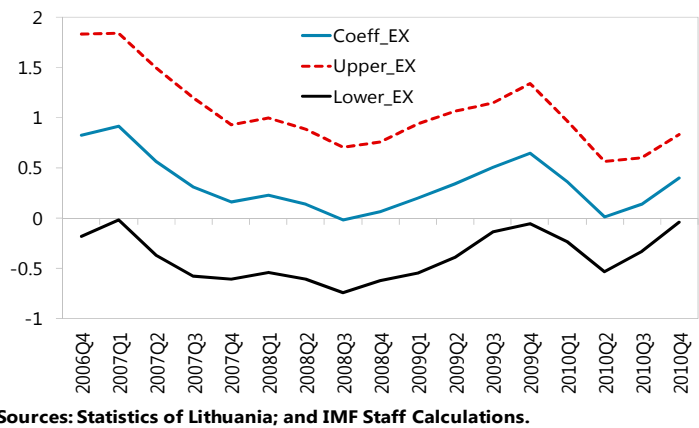

Note: Reported are time-varying elasticities from equation (3) using a moving window of 28 quarters (7 years). The following tax bases are used: wage bill (PIT), (lagged) operating surplus (CIT), personal consumption (VAT), and GDP (excise duty).

\section{Rolling window regressions confirm the time varying nature of tax elasticities, but the extent of variation differs across taxes (Figure 4):}

- $\quad$ The VAT elasticity has ranged between 0.5 and 1.5. In line with the prima facie evidence, the elasticity increased at the onset of the downturn, which was not a positive development given that the bases were contracting sharply. In the recovery phase, the elasticity is returning to its pre-recession level but remains above 1 fueling the recent recovery in tax collections.

- $\quad$ The PIT elasticity ranges between 0.9 and 1.4. It was on an upward trend between 2006-2008, then slightly declined during the recession, and is currently rebounding to its pre-recession level. The elasticity has stayed above unity in most part of the sample, in line with the progressivity of this tax. 
- $\quad$ The CIT elasticity ranges between 1 and 4 (the widest variation among taxes). It was on a declining path during the recession, but stabilized with the recent recovery. The wider variation of CIT elasticity compared to the one for other taxes can be explained by the relatively more uneven schedule of CIT payments within the year.

- $\quad$ The excise duty elasticity ranges between 0 and 1. Similar to PIT, it is currently rebounding. This may indicate the progress made by the authorities to counteract cross-border smuggling of fuel and cigarettes, which became particularly prominent in the wake of the recession.

\section{Panel data regressions}

We apply the pooled mean group (PMG) estimator of Pesaran et al. (1999) to analyze the VAT tax elasticities in a panel of ten new EU member countries. ${ }^{9}$ The advantage of the PMG is that it provides an estimate of long-run tax elasticities and allows assessing the deviation of tax revenues from their long-run equilibrium implied by these elasticities. The empirical specification takes the following form:

$$
\Delta \ln \left(T_{i t}\right)=\phi_{i}\left[\ln (T)_{i t-1}-\beta_{0}-\beta_{1} \ln \left(B_{i t-1}\right)\right]+\delta_{i} \Delta \ln \left(B_{i t}\right)+\alpha_{i}+\varepsilon_{i t}
$$

where $\beta_{1}$ is the (pooled) long-run tax elasticity coefficient, $\phi_{i}$ is the (country-specific) speed of adjustment to the long-run equilibrium, $\delta_{i}$ is the (country-specific) short-run adjustment coefficient, $\alpha_{i}$ is the country fixed effect capturing unobserved heterogeneity in tax systems across countries, and $\varepsilon_{i t}$ is the i.i.d. error term. We estimate specification (4) using VAT revenues adjusted for the impact of changes in statutory rates $(\mathrm{T})$ and personal consumption (B). The dynamics of the deviations from long-run equilibrium (the term in square brackets) during the recent recession would help to shed light on the cyclicality of tax revenues in Lithuania. In addition, the difference between current tax revenues and their long-run equilibrium at the end of the sample (if negative) would help to assess the potential for further VAT revenue improvements in Lithuania.

The PMG estimator is a panel data version of the error-correction model. It imposes a homogeneity restriction on the long-run relationship between VAT and its base, while allowing for the short-run effects to vary across countries. The PMG takes a middle ground between the two alternative estimation extremes:

- the fixed effects (FE) estimator, which imposes the homogeneity restriction on both long-run and short-run slope coefficients;

\footnotetext{
${ }^{9}$ The 10 new EU members were chosen as a comparator sample to Lithuania. Unfortunately, the panel data analysis cannot be extended to PIT, CIT, and EX due to considerable differences in respective tax systems across countries.
} 
- the mean-group (MG) estimator, which assumes that both long-run and short-run coefficients vary across countries.

The PMG specification can be tested against the MG and FE models using the Hausman test. The Hausman test does not reject the hypothesis of poolability of the longrun coefficients in both quarterly and annual regressions, favoring the PMG specification against the alternative MG specification. The evidence in favor of the PMG specification is even stronger when FE specification is considered as an alternative. Taken together, these results suggest that the long-run elasticity of unity for VAT holds for all new EU member countries. However, the VAT revenue collections can deviate from their long-run equilibrium at any particular time period and economic cycles can exacerbate these deviations.

\section{The PMG estimations produce strongly significant coefficients that are consistent with} the economic rationale (Table 1). The long-run tax elasticity coefficient is close to one in line with the neutral nature of the VAT explicitly assumed in previous work (see, e.g., Girouard and Andre, 1995). The speed of adjustment to the LR equilibrium is negative and significant, suggesting that about 10 percent of the deviation from the long-run equilibrium is adjusted within a quarter (column 1). Both results hold when real VAT and personal consumption are used in the estimations (column 2). The elasticity is slightly higher, but insignificantly different from one, when using annual data (columns 3 and 4). The speed of adjustment in the annual regressions suggests that about 60 percent of the deviation from the long-run equilibrium is adjusted within a year.

Table 1. PMG Estimation Results

\begin{tabular}{|c|c|c|c|c|}
\hline \multirow[t]{2}{*}{ Model } & \multicolumn{2}{|c|}{ Quarterly data } & \multicolumn{2}{|c|}{ Annual data } \\
\hline & $\begin{array}{l}\text { Nominal } \\
\text { (1) }\end{array}$ & $\begin{array}{c}\text { Real } \\
\text { (2) }\end{array}$ & $\begin{array}{l}\text { Nominal } \\
\text { (3) }\end{array}$ & $\begin{array}{c}\text { Real } \\
(4)\end{array}$ \\
\hline \multicolumn{5}{|l|}{ Long-run relationship } \\
\hline Constant & $\begin{array}{c}-0.0296^{* * *} \\
{[-3.91]}\end{array}$ & $\begin{array}{c}-0.0274^{\star * *} \\
{[-2.82]}\end{array}$ & $\begin{array}{c}-0.4264^{\star \star \star} \\
{[-7.21]}\end{array}$ & $\begin{array}{l}-0.6626^{\star \star *} \\
{[-6.97]}\end{array}$ \\
\hline Private consumption (LR elasticity) & $\begin{array}{c}0.9809 * * * \\
{[27.94]}\end{array}$ & $\begin{array}{l}0.9976^{\star * *} \\
{[12.17]}\end{array}$ & $\begin{array}{c}1.0273^{* * *} \\
{[39.95]}\end{array}$ & $\begin{array}{l}1.0746^{\star \star *} \\
{[20.90]}\end{array}$ \\
\hline \multicolumn{5}{|l|}{ Dynamics coefficients } \\
\hline Speed of adjustment & $\begin{array}{c}-0.1067^{* \star *} \\
{[-6.42]}\end{array}$ & $\begin{array}{l}-0.0850^{* * *} \\
{[-4.07]}\end{array}$ & $\begin{array}{c}-0.6264^{\star * *} \\
{[-6.09]}\end{array}$ & $\begin{array}{l}-0.6022^{\star \star *} \\
{[-5.68]}\end{array}$ \\
\hline Changes in private consumption & $\begin{array}{c}1.2120^{* * *} \\
{[8.96]}\end{array}$ & $\begin{array}{c}0.8372 * \\
{[1.94]}\end{array}$ & $\begin{array}{c}1.2865^{\star * *} \\
{[10.87]}\end{array}$ & $\begin{array}{c}1.1882^{* * *} \\
{[6.09]}\end{array}$ \\
\hline Number of obs. & 470 & 470 & 110 & 110 \\
\hline Hausman test, $p$-value (PMG versus MG) & 0.5783 & 0.3628 & 0.2076 & 0.3941 \\
\hline Hausman test, $p$-value (PMG versus FE) & 0.9598 & 0.9746 & 0.9504 & 0.9645 \\
\hline
\end{tabular}

Source: Statistics of Lithuania; and IMF Staff Calculations.

Note: t-statistics in parentheses. * **, and ${ }^{* *}$ denote significance at 1,5 , and 10 percent confidence levels. The reported speed of adjustment coefficients represent simple averages of country-specific coefficients. 


\section{Deviations of VAT revenues from their long-run equilibrium in Lithuania are closely related to the economic cycle (Figure 5). The deviations were positive during the pre-} recession boom period (2006-2008), but turned negative during the recession (2009-2010). In more recent quarters, tax collections have exhibited a tendency of rebounding to the long-run equilibrium on the back of the ongoing recovery, but still remain about five percent below the equilibrium. The relationship between the economic cycle and the revenue gap was different in the pre-2006 period. In particular, the revenue gap was positive in end-19992000 when the economy was still suffering from the Russian crisis spillovers. This result can be explained by the composition effect: the positive contribution of the private consumption to the GDP growth in 1999-2000 (3.2 ppt on average), which has consistently exceeded the real GDP growth (2.1 ppt on average). In fact, private consumption was the only component positively contributing to GDP growth in 1999, which has fueled VAT collections. This is in contrast to 2003-2004, when VAT revenue gap was negative. During this period, the contribution of private consumption ( $7 \mathrm{ppt}$ on average) to growth was lower than the output growth itself ( $8.8 \mathrm{ppt}$ on average).

\section{Comparison of VAT revenue gaps in Lithuania relative to other two Baltic countries reveals some similarities (Figure 5). First, the revenue gap was positive in all Baltic} countries during the 2006-08 period, when all three countries were benefitting from the tailwinds and the booming economic environment. Next, the revenue gap turned negative in all three countries following the bust. However, while in Estonia the revenue gap has returned back to positive at the beginning of 2009, the gap has stayed negative in both Latvia and Lithuania. The relatively better performance of revenues in Estonia can be largely explained by tighter revenue administration efforts as evidenced by outstanding C-efficiency scores (see Figure 3). Among three Baltics countries, Latvia has experienced the largest revenue drop during the recession, resulting in a negative revenue gap of about 20 percent at end-2010, which is four times larger than the 5 percent negative gap obtained for Lithuania. 
Figure 5. Deviation of VAT Revenues from their Long-Run Equilibrium
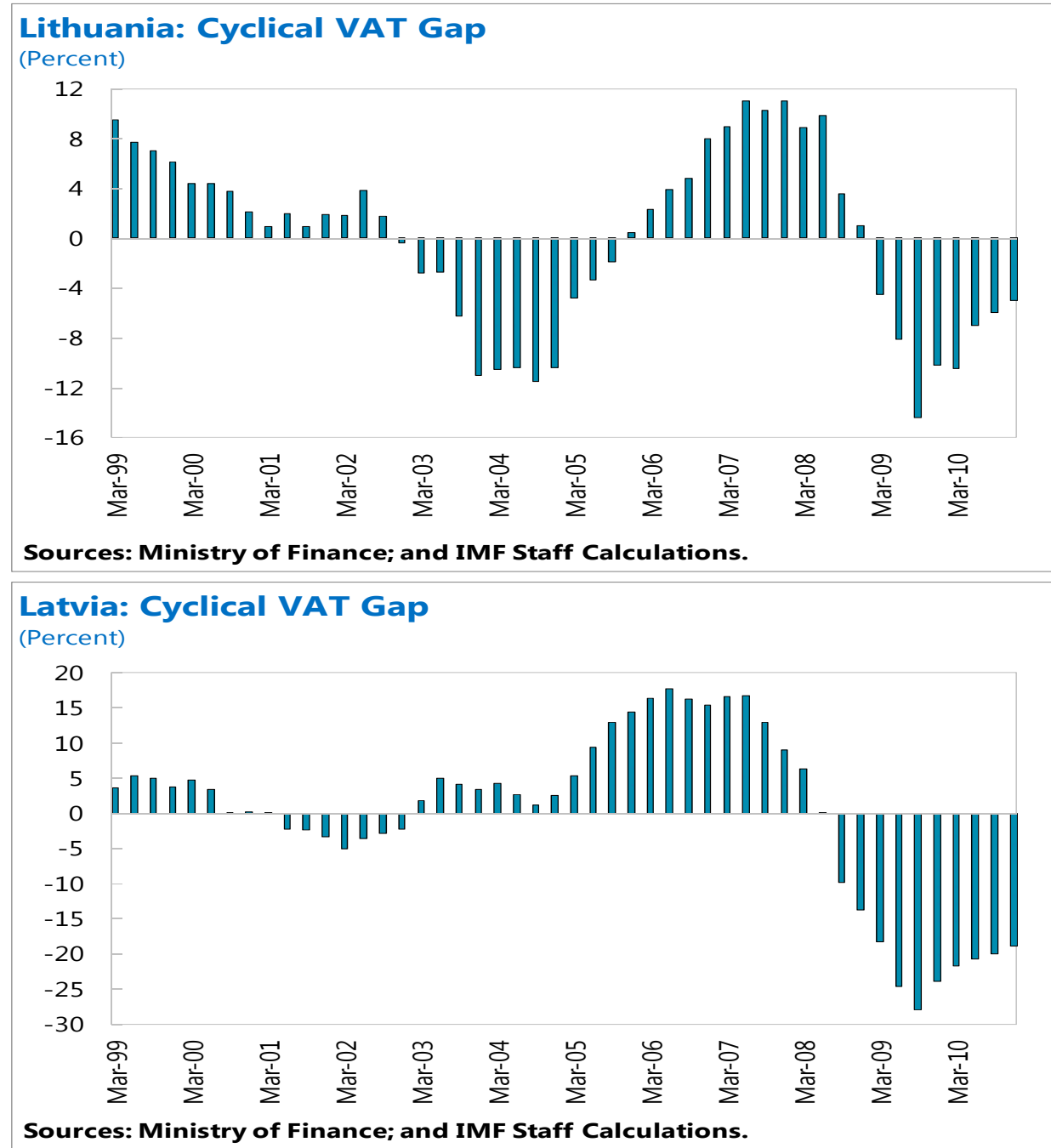

Sources: Ministry of Finance; and IMF Staff Calculations.

Estonia: Cyclical VAT Gap (Percent)

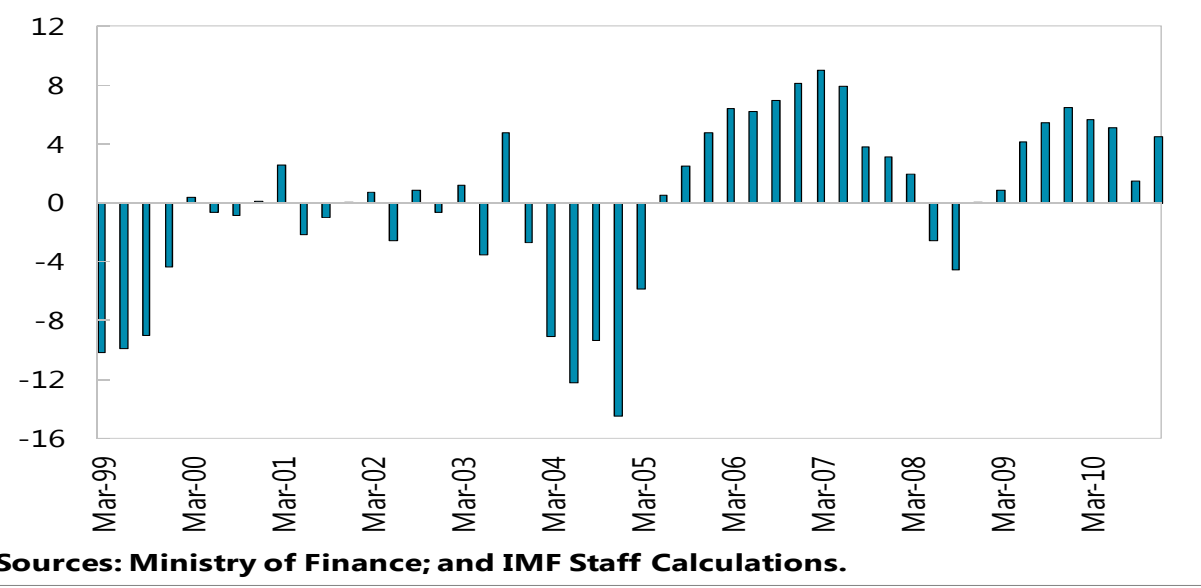




\section{Conclusion}

The above analysis provides empirical evidence on the variability of tax elasticities in

Lithuania. The deviation of short-run tax elasticities from their long-run counterparts can be driven by the composition effects in tax bases and cyclical movements in tax compliance.

These effects are in-line with the basic models of tax compliance, according to which during times of economic stress taxpayers tend to downplay risks of tax evasion (penalties) and put larger weight on potential upside gains from tax evasion (Brondolo, 2009). The direction of the variation differs across taxes, with most elasticities being flat during the recession and rebounding with the recent economic recovery. The panel regressions suggest that the most recent VAT collections in Lithuania are below their long-run equilibrium level by about 5 percent, implying that there is room for further improvement in VAT revenues in coming months.

The variability of tax elasticities has important policy implications. Deviations of tax elasticities from their long-run level should be taken into account when making short-term tax revenue projections. The deviation of short-term tax elasticities from their long-run level can be especially pronounced in new EU member countries with tax systems heavily relying on taxing flows (rather than stocks), which are more volatile compared to the EU average. For instance, long-run VAT elasticities should be adjusted above unity during the periods of rapid economic expansions and contractions. The extent of adjustment should vary across taxes, in line with the extent of their responsiveness to the business cycle. 


\section{REFERENCES}

Agha, A, and Haughton, J., 1996, "Designing VAT Systems: Some Efficiency Considerations," Review of Economics and Statistics, 78(3), pp. 303-08.

Aizenman, J., and Jinjarak, Y., 2008, "The Collection Efficiency of the Value Added Tax: Theory and International Evidence," The Journal of International Trade \& Economic Development, 17(3) pp. 391-410.

Aydin, B., 2010, "Cyclicality of Revenue and Structural Balances in South Africa," IMF Working Paper 10/216 (Washington: International Monetary Fund).

Bornhorst, and others, 2011, "When and How to Adjust Beyond the Business Cycle? A Guide to Structural Fiscal Balances," Technical Guidance Note, Fiscal Affairs Department (Washington: International Monetary Fund).

Bouthevillain, and others, 2001, "Cyclically Adjusted Budget Balances: An Alternative Approach," ECB Working Paper No. 77.

Brondolo, J., 2009, "Collecting Taxes During an Economic Crisis: Challenges and Policy Options,” IMF Staff Position Note 09/17 (Washington: International Monetary Fund).

Congressional Budget Office, 2009, "Measuring the Effects of the Business Cycle on the Federal Budget," (Washington: Congressional Budget Office).

De Masi, P., 2007, “IMF Estimates of Potential Output: Theory and Practice," IMF Working Paper 97/177 (Washington: International Monetary Fund).

De Mello, L., 2009, “Avoiding the Value-added Tax: Theory and Cross-Country Evidence," Public Finance Review, 37(1): pp. 27-46.

European Commission, 2011, Taxation Trends in the European Union, 2011 Edition (Luxembourg: Publications Office of the European Union).

Fedelino, A., Ivanova, A., and Horton, M., 2009, "Cyclically-Adjusted Balances and Automatic Fiscal Stabilizers: Some Computational and Interpretational Issues," IMF Technical Notes and Manuals 09/05 (Washington: International Monetary Fund).

Girouard, N., and André, C., 2005, "Measuring Cyclically-adjusted Budget Balances for OECD Countries," OECD Economics Department Working Paper No. 434.

IMF, 2010, Lithuania: Options for Revenue-Supported Fiscal Adjustment, IMF Selected Issues Paper No. 10/202 (Washington: International Monetary Fund).

Sancak, C., Velloso, R., and Xing, J., 2010, "Tax Revenue Response to the Business Cycle," IMF Working Paper 10/71 (Washington: International Monetary Fund).

Pesaran, H., Shin, Y., and Smith, R., 1999, "Pooled Mean Group Estimation of Dynamic Heterogeneous Panels," Journal of the American Statistical Association, 94: pp. 621-34. 